\title{
The Qarakhanid World
}

The mass migrations westward that resulted from the fall of the Turk Khaganate (552-740) and the Uyghur Khaganate (744-840) brought Turkic peoples closer to the borders of the Islamic cities than ever before. For instance, the Qarluqs and other Turkic groups started to settle in the Zhetysu region in present southeastern Kazakhstan by the mid-eighth century, during the first wave of migrations. Later the Qarluqs were united in a confederacy including Yaghma, Chigil, and other groups, expanding into the Kashghar and Ferghana regions that resulted the founding of the Qarakhanid Khaganate. The Oghuz appeared in the Syr Darya region around the same time, in the second half of the eighth century, and after conversion to Islam, rose from groups dwelling in the west Eurasian steppes to rulers of an empire that dominated the Middle East and Central Asia, known as the Saljuq Empire. The Bulghars, who moved to the Volga Region in the seventh century, established themselves as the dominant population in the region by the ninth century and united other Turkic groups as well as Slavic and Finno-Ugric elements living in this territory. ${ }^{1}$ They converted to Islam in the early tenth century and the Volga Bulghars became one of the main controllers of trade between Europe and the Islamic world in the tenth and eleventh centuries.

The formation of a frontier between the Islamic world and the Eurasian steppes sparked great interest of central Islamic rulers in the geography of the Turkic lands. Scholars who served at the Islamic courts collected information on the roads, cities, and peoples of this region, known as Atrāk (the plural form of the word "Turk"). One of the earliest descriptions of the Turkic peoples was written by Ibn Khurdādhbih (d. 913), who served at the 'Abbasid court and composed a book about roads to provinces and cities of the 'Abbasid Caliphate (750-1258); he also provided the early image of Turkic peoples in the Islamic world. ${ }^{2}$

1 Gerald Mako, “The Islamization of the Volga Bulghars: A Question Reconsidered," Archivum Eurasiae Medii Aevi (2011): 201.

2 Kitāb al-masālik wa al-mamālik, trans. Velikhanova, 6o, 65-66, 69. For the discussion of Arabic sources on the Turks, see Yehoshua Frenkel, The Turkic Peoples in Medieval Arabic Writings (New York: Routledge, 2015). 
Thus, in the ninth century the Turkic confederations became the closest neighbors of the Samanid Emirate (875-999) in Transoxiana and Khurasan, which together with the Khazar Khaganate (ca. 650-969), was the main supplier of slaves to the Abbasid Caliphate. The Samanid role in spreading Islam into the Turkic territories was significant, and the Central Asian frontier was the most important arena for jihad. ${ }^{3}$ Moreover, the Samanids' slave trade incited numerous attacks to the territories of the Turks, who were captured and sold to the 'Abbasid Caliphate to fill its armies and administration. The Samanids presented these conquests as part of the expansions of Islam. The newcomers, known in Arabic as ghulāms or mamlüks, were assimilated in the central Islamic lands through conversion to Islam and reaching high-ranking positions. Many of Turkic ghulāms who served at the 'Abbasid Caliphate (as well as other Islamic courts) moved up in the ranks and established their own polities such as the Ghaznavid Sultanate in large parts of Iran, Afghanistan and northwest India, and the Khwarazmshahs (1077-1231), who founded an empire in a vast region of present-day Central Asia and Iran, and later, the famous Mamluk Sultanate (1250-1517) of Egypt.

The Muslim conquest of Turkic territories and the ghuläm institution were not the main methods of Islamization among Turkic peoples. Peter Golden pointed out the role of merchants and Sufis in this process, particularly among the Qarakhanids. ${ }^{4}$ According to Jürgen Paul, the common assumption about Islamizing Sufis during the pre-Mongol period was probably first circulated by Bartold and cannot be properly proven as there is no evidence for early Sufi activities among the Turks. He stated that islamizers mentioned in the relevant records were not Sufis, "but defenders of Sunni orthodoxy and observance who had therefore come into conflicts with the authorities in Balkh and Tirmith."

The mass Islamization of Turkic peoples led to the founding of the first Turko-Islamic dynasties from Kashgharia to Anatolia and from northern India to the Volga Region beginning in the early tenth century. When dealing with the reasons for the mass conversion of Turkic peoples to Islam in the early tenth century, scholarship tends to share a predominant theory that can be summarized as follows: 1) through the adoption to Islam Turks sought to become independent; 2) it was an act towards legalization of their conquests; 3) they sought to protect their trade routes and improve relations with commercial

3 Deborah G. Tor, "The Islamization of Central Asia in the Sāmānid Era and Reshaping of the Muslim World," Bulletin of the School of Oriental and African Studies 72, no. 2 (2009): 284.

4 Peter B. Golden, Central Asia in World History (Oxford: Oxford University, 2011), 69.

5 Jürgen Paul, "Islamizing Sufis in Pre-Mongol Central Asia," in Islamisation de l'Asie centrale: Processus locaux d'acculturation du VII ${ }^{e}$ au XI $I^{e}$ siècle (Cahiers de Studia Iranica 39), ed. Étienne de la Vaissière (Paris Louvain: Peeters, 2008), 314. 
partners in the Islamic world. It should be also noted that the Islamization of Turkic peoples was crucial to both their representation in China and connecting the Islamic and the Sinitic worlds.

In this chapter, I discuss the Qarakhanids and their main trade partners in the Turko-Islamic world together with early Qarakhanid history, as this is important for an understanding of their situation between China and the Islamic world. I will also outline the Qarakhanids' neighbors to the East.

\section{$2 \quad$ Notes on the Qarakhanid Image and Origin}

The names by which the Qarakhanids are known to us were not their own. The Qarakhanids were recorded in medieval Islamic texts as al-Khāqāniyya ${ }^{6}$ and Âl-i Âfrāsiyāb. ${ }^{7}$ The Qarakhanid period marked a turning point of Islamization of the Turkic world and the Turkification of Transoxiana. The present political shape of Central Asia was formed during this period; it became Turkic and Islamic. All these events reflected the image of Central Asia and its relationship to the outside world.

In most modern scholarly works, Qarakhanid history is usually considered to have started in the middle of the tenth century, around the time of their Islamization. This can be explained by the lack of data sources, both written and archaeological, on the pre-Islamic history of the Qarakhanids. This approach makes the Qarakhanids more "western" and pulls them away from their eastern heritage, which is crucial to understanding their image and acceptance in the non-Islamic Turko-Sinitic world. However, some scholars mark the beginning of the Qarakhanids as starting in the year 840 , when a

6 al-Khāqāniyya ("The Khaqanian Dynasty”), named after the title of the Qarakhanid rulers. Dìwān lughāt al-Turk, trans. Auezova, 908 .

7 Āl-i Âfrāsiyāb ("The House of Afrasiyab"), named after the legendary king of Turan in Firdawsì's Shāhnāma. The name of Afrasiyab, who was a king of Turan in ancient Iranian mythology, is closely associated with the Turks in tenth- to eleventh-century Arabic and Persian literature. Therefore, the Turks who came to power after the Samanids in Central Asia were considered to be descendants of Afrasiyab. According to the Qarakhanid scholars, Afrasiyab was known among the Turks as Tonga Alp Er ("The Man Brave as a Tiger"), also known as Alp Er Tonga. Dīwān lughāt al-Turk, trans. Auezova, 851, 1014; Qutadghu Bilig, trans. Dankoff, 48; for the Turkic text, see Qutadghu bilig, ed. and trans. Arat, vol. 1, 43. Hua Tao suggested that the Qarakhanids connected themselves with Afrasiyab under a Saljuq influence. Hua Tao, "The Muslim Qarakhanids and Their Invented Ethnic Identity," in Islamisation de l'Asie centrale: Processus locaux d'acculturation du VII e au XI $I^{e}$ siècle (Cahiers de Studia Iranica 39), ed. Étienne de la Vaissière (Paris Louvain: Peeters, 2008), 344. 
new Turkic confederation in Zhetysu emerged after the fall of the Uyghur Khaganate. ${ }^{8}$ In this study, I follow this hypothesis.

Due to the multi-tribal components of the new confederation, the origins of the Qarakhanid ruling elite are debatable. ${ }^{9}$ The most recent theory, based on numismatic evidence, has been suggested by Boris Kochnev, who claimed that the Qarakhanid origin was related to the Igdish (Idgish) clan of the Chigil group, which was one of the components of the Qarluq confederation. ${ }^{10}$ At the same time Chinese sources from the Song period viewed the Qarakhanids as the descendants of the Uyghur Khaganate along with the Xizhou Uyghurs (9th-13th centuries) and Ganzhou Uyghurs (9th-11th centuries):

初, 回鶻西奔, 族種散處。故甘州有可汗王, 西州有克韓王, 新復州 有黑韓王, 皆其後焉。11

In the beginning, when Huigu [Uyghurs] ran to the west, their tribes and clans scattered in different places. Therefore, there were kehan [Khagan] in Ganzhou [Zhangye], kehan in Xizhou [Turfan] and heihan [Qarakhan] in Xinfuzhou [Khotan]. They are all descendants of Huigu.

Following this tradition, the Qarakhanids are often considered to be of Uyghur origin in Chinese scholarship. ${ }^{12}$ However, the Song authors in this passage mainly referred to the historical event that caused mass migrations of the Turkic peoples to the west, rather than to the origin of the Qarakhanid ruling elite.

8 Pritsak, "Die Karachaniden," 84; Wei, Kalahan wangchao, 62; Peter B. Golden, "The Karakhanids and Early Islam," in The Cambridge History of Early Inner Asia, ed. Denis Sinor (Cambridge: Cambridge University Press, 1990), 354-358. This hypothesis was also followed in the multivolume unesco History of Civilisations of Central Asia, see Elena A. Davidovich, "The Karakhanids," in History of Civilizations of Central Asia: The Age of Achievement A.D. 750 to the End of the Fifteenth Century, ed. Muhammad S. Asimov, and Clifford E. Bosworth (Paris: UnEsCO, 1998), vol. 1, part 1, 126.

9 For different theories of the origins of the Qarakhanids, see Pritsak, "Die Karachaniden," 21-22; Muhammet Kemaloğlu, "Karahanlıların Menşe ve Kuruluş Faraziyeleri," Hikmet Yurdu 6, no. 11 (2013): 415-424.

10 Boris D. Kochnev, Numizmaticheskaia istoriia Karakhanidskogo kaganata, 991-1209 gg (Moscow: Sofiia, 2006), 148. Liu Yingsheng also proposed, based on Jin sources that the ruling elite of the Qarakhanids might be of Chigil origin. Liu Yingsheng, "A Century of Chinese Research on Islamic Central Asian History in Retrospect," Cahiers d'Asie centrale 9 (2001): 121 .

11 Song shi, 490: 14117.

12 Liu Yingsheng rejects the Uyghur hypothesis. For the discussion of this issue, see Liu, "A Century of Chinese Research," 119-120. 
If we accept that the history of the Qarakhanids started in 840 after the Uyghur collapse, when the Qarluqs in Zhetysu claimed leadership of the Turkic nomads calling themselves as Khagans, then we can also assume a shift of a century in Qarakhanid history, because the Qarluqs started to reside in Zhetysu after the fall of the Turk Khaganate in 740. For this reason, Ömer Soner Hunkan proposed beginning Qarakhanid history from 766, when the Qarluqs replaced the western Turks as a leading local power. He also suggested dividing Qarakhanid history into three periods: from Yabghunate to Khaganate (766-840), pre-Islamic Khaganate (840-920), and the Islamic Khaganate $(920-1212) \cdot{ }^{13}$ Moreover, by summarizing names applied to the Qarakhanids in Islamic sources, he claimed that the polity founded by them should be called the Turk Khaganate (Türk Hakanliği). ${ }^{14}$

But even if we start Qarakhanid history from 840, we still have a period of around one hundred and fifty years that is almost completely undocumented and offers no numismatic materials. ${ }^{15}$ It should be mentioned here that there are, in fact, some rare coins datable to the tenth century found in Zhetysu that resemble Chinese coins (with the characteristic square hole), but the most interesting fact about them is that the words placed along the four sides of the hole are written in Kufi. Vladimir Nastich, who has studied these specimens and suggested to term them "proto-Qarakhanid coins," identified the words malik, arām, yīnäl and jïg/chïg or chīh. ${ }^{16}$ However, Boris Kochnev assumed that these materials have yet not been sufficiently studied and thus cannot be used as a source for Qarakhanid history. ${ }^{17}$ Nevertheless, these specimens are unique and illustrate the Islamic and Sinitic features of the Qarakhanids. Chinese-style coins with local scripts had also widely been minted in that region before the time of the Qarakhanids. ${ }^{18}$ However, the "proto-Qarakhanid" coins are the only example of Chinese-style coins with Arabic inscriptions that belonged to the newly Islamized transitional coinage of Central Asia. These coins demonstrate that the new Islamic dynasty in the region was allowed to use Arabic inscriptions on the familiar cash form before an entirely new coinage was introduced.

13 For the periodization, see Ömer Soner Hunkan, Türk Hakanliği (Karahanlilar): KuruluşGelişme-Çöküş, 766-1212 (Istanbul: IQ Kültür Sanat Yayıncılık, 2011).

14 Ibid, 59-64.

15 Paul, Zentralasien, 148.

16 Vladimir N. Nastich, "Monetnye nakhodki iz Kazakhstana i Kirgizii," in Vtoraia Vsesoiuznaia Numizmaticheskaia Konferentsiia (Moscow: Akademiia Nauk sssR, 1987), $5^{2-53}$.

17 Kochnev, Numizmaticheskaia istoriia, 149.

18 Aleksandr Kamyshev, "Novye arkheologicheskie nakhodki s gorodischa Sadyr-Kurgan," Izvestia Natsional'noi Akademii nauk Respubliki Kazakhstan 1 (2009): 286-287. 
Muslim written sources on the "proto-Qarakhanids" or pre-Islamic Qarakhanids provide detailed information on the flourishing trade roads and cities in Zhetysu that already connected the Islamic world with China. ${ }^{19}$ Close to the Islamization period of the Qarakhanids, however, geographical information in Islamic sources on Zhetysu became very fragmentary.

More written sources, as well as numismatic materials, appear starting from the time of the Islamization of the Qarakhanids. The tenth century marked a turning point in the Islamization of Turkic Central Asia, starting from the Qarakhanid ruler Satuq Bughra Khan (d. 955-56), who probably converted to Islam around the middle of the tenth century or even earlier. When a leader converted, his kinship group usually followed suit, ${ }^{20}$ and this explains the mass conversions among Turkic nomads in this period as depicted in Islamic sources. The Qarakhanid rulers had a reputation as true and pious Muslims in Islamic sources. ${ }^{21}$ The first Islamic coinage of the Qarakhanids appeared after the successful conquest of the Samanid territories in Transoxiana, showing that a new Islamic power was established in this region. Newly islamized Qarakhanid rulers emphasized their status using the title Mawla Amir al-Mu'minin and Mawla Rasül Allāh, which can be understood to mean "Agent of the Caliph" and "Agent of the Prophet."22 The Mawla status was a very important one in early Islamic history, which had been previously used to mean freed slaves and non-Arabian converts to Islam, but its meaning had shifted by the Abbasid period. The term Mawla Amìr al-Müminin, which emerged during al-Mansur's reign (754-775), was used as an honorary political title and should not be confused with the term Mawla from earlier periods that indicated a low social status. The new title implied nothing about the social origin or the current status of the owner. The usage of these titles by the Qarakhanids is essential to understanding how they might have presented themselves at the Chinese court.

19 Hudūd al-čalam, trans. Minorsky, 97-99; Kitāb al-masālik wa al-mamālik, trans. Velikhanova, 65-66; Mulhaqāat al-șurāh, trans. Vohidov and Aminov, 102.

20 Golden, Central Asia in World History, 70.

21 According to the Arab historian Ibn al-Athîr, the Qarakhanid rulers were pure Muslims, who drank no wine, fought for their religion, and patronized science. Al-Kämilfı̌al-tàrīkh, ed. Tornberg, vol. 9, 210-213; Al-Kämil fí al-tärīkh, trans Bulgakov and Kamoliddin, 184186. The Gaznavid historian Gardizī also noted that the Qarakhanid ruler, Yusuf Qadir Khan (998-1026/1026-1032), drank no wine, "as it is not customary for the kings of Transoxiana, especially the Turkic kings (malikān Turkān)." Zayn al-akhbār, ed. Habībī, 188. Tamghach Khan Ibrahim (1040-1068) was called "Steadfast in Faith" (mutadāंiȳn), who acted according to Islamic law. Talkhīṣ majma' al-ādāb fi mújam al-alqāb, ed. Jawar, vol. 4, 650-651.

22 Al-Kämil fì al-ta’rīkh, ed. Tornberg, vol. 9, 70; Al-Kämil fì al-ta'rīkh, trans. Bulgakov and Kamoliddin, 158; Kochnev, Numizmaticheskaia istoriia, 132, 15o. 
The Qarakhanid arrival in Transoxiana, starting from the 992 conquest of Bukhara the capital of the Samanids, signaled a definitive shift from Iranian to Turkic dominance in Central Asia. At the same time, through the Qarakhanids, the Tarim Basin became closely linked to the Islamic world that started the Islamization process in present-day Xinjiang. The Qarakhanid conquest of Khotan and Kucha marked the end of the Turkification process in the Tarim Basin, which had been started by mass nomad migrations touched off by the fall of the Uyghur Khaganate in Mongolia. The political shape of present-day Central Asia had indeed been formed during the time of the Qarakhanids. The exact date of the conquest of the Khotan and Kucha kingdoms remains in dispute. The reign title of the last Khotan king was used until 10o6, therefore, Zhang Guangda and Rong Xinjiang suggested that the Qarakhanids conquered Khotan in 1006. ${ }^{23}$ However, the Qarakhanid military presence in Khotan can be observed much earlier. For instance, in 971 the Khotan king sent a letter to Emperor Taizu of Song (96o-976) to inform him about their victory over the Qarakhanids. ${ }^{24}$

Another title that appeared on early Islamic Qarakhanid coins, Malik alMashriq ("King of the East"), looks like a claim to sovereignty in Transoxiana and Khurasan. However, these ambitions were stopped by the alliance between the Qarakhanids and the Ghaznavids, another newly islamized Turkic dynasty in Central Asia and former Samanid territories had been divided between them, indicating the Amu Darya as a border.

The Qarakhanids continued their Turkic political traditions, viewing the state as the collective property of the royal clan and dividing the state into a western part with the capital in Samarqand and an eastern part with the centers in Balasaghun and Kashghar around 1040. While Islamic sources of this period contain more detailed information on the western Qarakhanids, accounts in Chinese sources focus on the eastern part of this state. Therefore, it is necessary to combine information provided in these two types of sources.

The Qarakhanid rulers, together with the Islamic honorary titles Malik alMashriq wa al-Șin "King of the East and China" and Sulțān al-Sharq wa al-Ṣin "Sultan of the East and China," used also a Turkic title, namely Tabghach Khan,

23 Zhang Guangda 张广达, and Rong Xinjiang 荣新江, “Guanyu Tangmo Songchu Yutian guo de guohao nianhao ji qi wangjia shixi wenti 关于唐末宋初于阗国国号 年号及 其王家世系问题 [On the Issue of the reign title of the Khotan kingdom and its dynasty in the late Tang and early Song periods]," in Dunhuang Tulufan wenxian yanjiu lunji 敦煌吐鲁番文献研究论集 [Collected Essays on Dunhuang and Turfan Texts] (Beijing: Zhonghua shuju, 1982), 183-185. 
meaning "Khan of China." 25 The Turkic name of China "Tawghāj/Tabghāch" is considered to be derived from Tuoba, the clan name of the non-Han Northern Wei (386-584) emperors. ${ }^{26}$

Why did the Qarakhanids refer to themselves as "Khans, Kings and Sultans of China"? The Tang dynasty built an empire whose territory and protectorates extended to Turfan, Kashgharia, and even to Transoxiana and Khurasan. Some of these territories were not under Tang civil administration, but the Tang army ensured that the local rulers accepted the Tang as their master and thus supported Tang interests in the Silk Road trade. ${ }^{27}$ Islamic sources of the Qarakhanid period also recorded that these lands once belonged to China. ${ }^{28}$ Moreover, in the Qarakhanid world people believed that China had originally been divided into three parts: Tawghāj (south China), Khitāy (north China) and Barkhān (in Kashghar). ${ }^{29}$ This shows that people still remembered the glory of Tang China and explains why the Qarakhanids - who ruled in Kashgharia and Transoxiana, which had once been a part of the Tang protectorate - used the titles to indicate that these territories now belonged to them and this fact gave them a sense of prestige and pride.

25 Dīwān lughāt al-Turk, trans. Auezova, 424.

26 However, some scholars link the word Tawghāj/Tabghāch with Tangjia "The House of Tang." Yang Shao-yun claims that the Tangjia theory is more appropriate than the Tuoba theory, relying on the eleventh-century Chinese source Juanyou lu (Records on the Weariness of Traveling), some fragments of which survived in the encyclopedia Songchao shishi leiyuan from the Southern Song period, which states that "until today in Guangzhou foreigners refer to China as 'The House of Tang and to Chinese as "The language of Tang" (至今廣州胡人, 呼中國為唐家, 華言為唐言). Songchao shishi leiyuan, 77: 10o9; Yang Shao-yun, "Fan and Han: The Origins and Uses of a Conceptual Dichotomy in Mid-Imperial China, ca. 500-1200," in Political Strategies of Identity Building in Non-Han Empires in China, ed. Francesca Fiaschetti, and Julia Schneider (Wiesbaden: Harrassowitz, 2014), 27-28. The Tangjia theory is not acceptable due to the fact that the term appeared in the work of the early seventh-century Byzantine historian Theophylact Simocatta, who wrote about historical events during the reign of the emperor Maurice (582-602). In his History, Simocatta mentioned a place called Taugas or Taugast that refers to China and was derived form the Turkic name for China. The author stated that he utilized the letter of the Turkic Khagan that was received in 598. This means that the term Tabghāch had been used among the Turks before the Tang dynasty. For the description of Taugas by Theophylact Simocatta, see Michael and Mary Whitby, The History of Theophylact Simocatta: An English Translation with Introduction and Notes (Oxford: Clarendon Press,

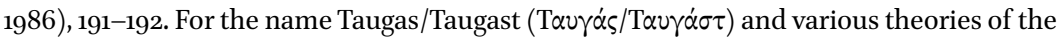
origin of the Turkic word Tabghāch, see Zhang Xushan, "On the origin of "Taugast" in Theophylact Simocatta and the Later Sources," Byzantion 8o (2010): 485-501.

27 Harold M. Tanner, China: A History (Indianapolis: Hackett, 2009), 167, 174-176.

28 Hudūd al-āalam, trans. Minorsky, 83-86; Ṭabä’’ al-hayawān, ed. and trans. Minorsky, 18.

29 Dīwān lughāt al-Turk, trans. Auezova, 424. 
The fall of the dynasty is connected with the Qarakhanid-Khwarazmshah confrontation, which ended with the victory of Muhammad Khwarazmshah (1200-1220) in 1212. Muhammad Khwarazmshah gave the order to kill not only his opponent 'Uthman ibn Ibrahim (1203-1212), but also other members of the Qarakhanid dynasty. ${ }^{30}$ However, some Qarakhanid dynastic members continued to rule as Mongol governors. For instance, Darhan Kidirali and Gaybullah Babayar suggested that a tomb in the mausoleum known as "Daut-bek Kesenesi" belongs to the one of the last Qarakhanids, Isfihsalar ibn Ilyas, who was a governor in Talas (also known as Taraz) until 1262. ${ }^{31}$

\section{The Qarakhanid Trade Partners in the West}

The mass conversion to Islam among the Turkic peoples was an important step to emerging the first Turko-Islamic empires in Eurasian history. The Qarakhanids had established diplomatic relations with most of the neighboring Turko-Islamic dynasties, namely the Ghaznavids, the Saljuqs, the Khwarazmshahs, and the Volga Bulghars, strengthened in certain cases by marriage alliances. The main driving force behind the political alliance was the economic interest of the Qarakhanids.

The Qarakhanids sought to establish themselves as middlemen in international trade between the Turko-Islamic and Sino-Tibetan worlds. In addition to the typical nomadic products, the Qarakhanids exported commodities obtained from other places. Chinese fabrics were highly prized in the Islamic world, and the Qarakhanids exported silk and other types of fine fabric from China to the west. However, Chinese silk was no longer the primary commodity. This book demonstrates that Qarakhanid merchants brought precious metals, herbs and medicines, including tea from China. At the same time, rarities that the Qarakhanids obtained from their neighbors in the Islamic world were transferred to China. Since the pre-Islamic period, the Qarakhanids had sought to obtain various types of rarities and spices from sedentary societies. For instance, Ughuljaq (Oghulchak) Qadir Khan personally liked the brocade, sugar, and sweets that had been introduced by Samanid merchants. ${ }^{32}$

By the eleventh century, the Qarakhanids were involved in the international trade network, which had already been rather complex before the Mongol

\footnotetext{
$30 \quad$ Bartold, Turkestan, 430-431.

31 Darhan Kidirali, and Gaybullah Babayar, "Taraz'da bulunan son Karahanli hükümdarlarindan birine ait mezar aniti," Gazi Türkiyat 18 (2016): 19-41.

32 Mulhaqāt al-șurāh, trans. Vohidov and Aminov, 102.
} 
globalization. This gave the Qarakhanids access to Chinese trade networks and commodities through diplomatic relations with the Liao and the Song, India through the Ghaznavids, Iran and Asia Minor through the Saljuqs, and Europe through Khwarazm and Volga Bulgharia.

\subsection{The Volga Bulghars}

Trade, specifically the fur trade, was the main impetus for the emergence of the Volga Bulghars and their conversion to Islam. ${ }^{33}$ The geographical location in the center of the so-called Fur Road turned Volga Bulgharia into a key region between northern Europe and Central Asia. The Volga Bulghar Khaganate became the first empire located in the center of the Fur Road. ${ }^{34}$ The term "Fur Road," also known as the "Steppe Road," is applied in contemporary scholarship to the Northern Eurasian trade networks in the pre-modern period. They were used for transportation of pastoral products as well as furs and fur items to other parts of the world, including the Middle East, Central Asia and East Asia, linking the Eurasian grassland and agricultural regions, and were much wider than the Silk Road. ${ }^{35}$ The Volga Bulghars were involved in trade with the Vikings, who sailed from Northern Europe to Iceland and Greenland, even reaching North America around the year 1000. ${ }^{36}$ The Vikings actively traded in the Slavic and newly Islamized Bulghar worlds. ${ }^{37}$ They shipped various goods from their realm in exchange for commodities of the Islamic world, including woven silk, which was produced in Central Asia and has been found in Viking burial sites. ${ }^{38}$

The Volga Bulghars' main trade partners in Central Asia were the Samanids and later the Qarakhanids continued commercial relations with them. The importance of Volga Bulgharia in the Qarakhanid world is confirmed by its inclusion on a map of the Turks and their neighbors that appeared in Diwwan

33 Mako, "The Islamization of the Volga Bulghars," 199-223.

34 Ibid, 209.

35 For the term "Fur Road" and its scope, see Roman K. Kovalev, "The Infrastructure of the Northern Part of the 'Fur Road' Between the Middle Volga and the East During the Middle Ages," Archivum Eurasiae Medii Aevi 11 (2000-2001): 25-64; Paul, Zentralasien, 175; Jonathan K. Skaff, Sui-Tang China and its Turko-Mongol Neighbors: Culture, Power, and Connections, 580-80o (Oxford: Oxford University Press, 2012), 8.

36 For the archaeological expeditions in North America and discovery of a group of housesites of Norse origin, see Helge Ingstad, and Anne Stine Ingstad, The Viking Discovery of America: The Excavation of a Norse Settlement in L'Anse Aux Meadows, Newfoundland (New York: Checkmark Books, 2001).

37 Risāla / Ibn Fadlān, trans. Lunde and Stone, 45-47; Kitāb al-a lāk al-nafisa, ed. Goeje, 141.

38 For the Scandinavian silk items from the Vikings' burials and its Central Asian origin, see Marianne Vedeler, Silkfor the Vikings (Havertown: Oxbow, 2014). 
lughāt al-Turk written by the Qarakhanid scholar Maḥmūd al-Kāshgharī in $1074{ }^{39}$ Bulghar merchants sailed to Khwarazm, bringing commodities from their realm as well as what they obtained from the Vikings. From Khwarazm these items were transported to the Qarakhanid realm. The Qarakhanids transported these items to China, thereby connecting the complex network trade between Scandinavia, the Islamic world, and China. However, Bulghar merchants could also pass farther to the east. Maḥmūd al-Kāshgharī recorded some descriptions of merchants from Sūwār, a flourishing city in Volga Bulgharia in the eleventh century. ${ }^{40}$

The Volga Region was beyond the influence of any sedentary empire; therefore, written sources on early history of the Volga Bulghars are rare, making it difficult to determine the exact beginning of their history. ${ }^{41}$ Muslim authors first started to provide evidence of the Volga Bulghars on the eve of the tenth century during the period of their conversion to Islam. For instance, Ibn al-Faqih mentioned the country of the Burjān, which is Bulghar in his work dated to $903 .{ }^{42}$ Ibn Rusta, a Persian geographer and explorer who made the pilgrimage to Mecca in 903 and wrote a geographical compendium, mentioned the Bulkārs (Bulghars) and their Muslim ruler Almish. ${ }^{43}$ His description of Volga Bulgharia makes him a useful source on early history for this infrequently-described region.

The Bulghar ruler Almish dispatched an envoy to Baghdad in hopes of allying with the 'Abbasid Caliphate. In response, a mission led by Ibn Fadlān was sent from Baghdad that reached the royal camp of the Bulghar ruler in 922. ${ }^{44}$ The envoy went to Ray and Nishapur, then reached Bukhara, the Samanid capital, and followed to the Khwarazmian cities Kath and Gurganj, then crossing the territories of the Oghuz, Pechenegs, and Bashqirts reached the Volga Bulghars. ${ }^{45}$ Later this itinerary was most likely used by the Bulghar merchants, who traded in the Qarakhanid realm bringing merchandise from the north. Ghaznavid and Saljuq scholars al-Bīrūnī and Marwazī mentioned trade and commodity exchanges between the Volga Bulghars and Finno-Ugric people called Îsū and Yūrā, who offered highly prized sable and other fine furs. ${ }^{46}$ This

\footnotetext{
39 For the facsimile of the map, see Dīwān lughät al-Turk, trans. Auezova, 1289-9o.

40 Ibid, 316, 2529.

41 Mako, "The Islamization of the Volga Bulghars," 200.

42 Kitāb al-buldān, ed. Goeje, 270-271.

43 Kitāb al-a lāk al-nafisa, ed. Goeje, 141-142.

44 Risāla / Ibn Fadlān, trans. Lunde and Stone.

45 For the map of his journey, see Ibid, 4-25.

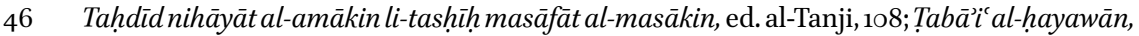
ed. and trans. Minorsky, 34-35.
} 
information confirms the existence of flourishing fur trade in the eleventh and twelfth centuries.

Trade was crucial for the Volga Bulghars and conversion to Islam improved their commercial relations with the main partners in the Islamic world such as the Samanids and later the Qarakhanids. The Volga Bulghars became one of the main suppliers of furs to Central Asia.

\subsection{The Ghaznavids}

By the middle of the tenth century, the Turkic ghuläms within the Samanid Empire established self-governance in Ghazna in present-day Afghanistan. Under the rule of Sabuktigin (977-997), a slave brought from Turkistan ${ }^{47}$ and his son Mahmud (998-1030), the new Turko-Islamic state became one of the key political players in the region. At its zenith, the Ghaznavids, a Persianized Islamic dynasty of Turkic origin, ruled eastern Iran, Khwarazm, Baluchistan, and northwestern India. The dynasty was named after the capital Ghazna in modern scholarship and as mainly known by the name of its founder, Sabuktigin, in primary sources. ${ }^{48}$

The Turks were the largest ethnic component of the Ghaznavid armies, composed mostly of military slaves from different ethnic groups around the Ghaznvaid Empire and its neighbors, such as the Qarluqs, Yaghma, Qay, Tukhsi, Chigil, and later from the Kirghiz, Tatars and Khitans. ${ }^{49}$ Therefore, the persistence of nomad practices and culture was essential, at least during the early Ghaznavids. However, the fact that from the very beginning the bureaucratic personnel was made up of Persians, who occupied official positions of all levels from secretaries to viziers, caused the rapid Persianization of the Ghaznavid ruling elite. The Ghaznavid rulers were known as patrons of Persian culture and became culturally Persianized to a higher degree than other contemporary Turko-Islamic dynasties, such as the Qarakhanids and the Saljuqs. ${ }^{50}$

The Ghaznavids shared a border with the Qarakhanids, who were not always good neighbors, especially in the initial stage of the state formation. However, when the Amu Darya formed a border between the Ghaznavid and Qarakhanid territories through a peace treaty, both polities sought to establish diplomatic relations strengthened by marriage alliances. The Qarakhanids served as the

Sabuktigin was from Barskhan in the Zhetysu region that corresponds to what is now the northeastern part of Kyrgyzstan.

48 Paul, Zentralasien, 2012, 144.

49 Bosworth, The Ghaznavids, 109.

50 Clifford E. Bosworth, "Ghaznavids," Encyclopcedia Iranica, ed. Ehsan Yarshater (New York: Encyclopædia Iranica Foundation, 2001), x/6, 578-583, http://www.iranicaonline.org/ articles/ghaznavids. 
main suppliers of luxury Chinese commodities into the Ghaznavid realm as a means to gain access to the Indian market.

Relations between the Qarakhanids and the Ghaznavids are very well documented, with detailed information on diplomatic protocols, ceremonial receptions, and gift exchanges with comprehensive lists of commodities presented between the monarchs. I discuss the case of Qarakhanid-Ghaznavid relations in more detail in Chapter 2 to demonstrate the complexity of trade in the Qarakhanid world.

\subsection{The Saljuqs}

The Saljuq Turks, a household from the Qiniq Oghuz group that were known in Islamic sources as the Ghuzz, Turkman or al-Saljūqiyya, dominated the Middle East and Central Asia. These Turks were recent converts to Islam when they began to migrate westward as a military power in the early eleventh century. After the capture of Baghdad in 1055, the leaders of the Saljuqs assumed the title of "Sultan" and considered themselves guardians of the 'Abbasid Caliphate. In the mid-eleventh century, the Saljuqs steadily expanded the territory under their control until they had created an empire stretching from Transoxiana to Anatolia that centered in Iran. ${ }^{51}$

Traditional Turkic political inheritance, which viewed the state as the collective property of the royal clan and divided territory between a deceased leader's sons, fragmented the Saljuq Empire (ca.1040-1194) into sultanates and emirates. The Saljuqs had lost power everywhere by the end of the twelfth century except Anatolia, which was known to Muslim chroniclers as Rum. Therefore, a Saljuq ruler of the Sultanate in Anatolia (ca. 1081-1308) was known in the Islamic world as Sulțān al-Rūm ("Sultan of Rum"), Șāhib al-Rūm ("Master of Rum") or Malik al-Rüm ("King of Rum"). ${ }^{52}$

Diplomatic gifts sent from the Qarakhanids serve as a fine illustration of goods that were valued outside of the Qarakhanid realm and could also be involved in trade. The Qarakhanid diplomatic gifts sent to the Saljuq Sultans consisted of horses, clothes, and spices. ${ }^{53}$

$5^{1}$ For the early history of the Saljuqs and the formation of the Saljuq Empire, see Andrew C.S. Peacock, Early Seljūq History: A New Interpretation (London: Routledge, 2010) and Peacock, The Great Seljuk Empire.

52 Dimitri Korobeinikov, "The King of the East and the West: The Seljuk Dynastic Concept and Titles in the Muslim and Christian Sources," in The Seljuks of Anatolia: Court and Society in the Medieval Middle East, ed. Andrew C.S. Peacock, and Sara Nur Yildiz (London: I.B. Tauris, 2013), 79. For the history of the Saljuq Sultanate of Rum, see Peacock and Yildiz, The Seljuks of Anatolia.

53 Mirāàt al-zamān fì tärīkh al-a ayān, ed. Sevim, 172. 
By the end of the eleventh century, the Saljuqs, who defeated the Ghaznavids in the battle of Dandanaqan in 1040 and established the Great Saljuq Empire in territories from Khurasan and Iran to Syria and Asia Minor, imposed their formal supremacy on the Qarakhanids. However, the Qarakhanids continued to rule in the region and established close relations with the Saljuq ruling family through marriage alliances. For instance, the first wife of the Saljuq Sultan Malik Shah I (1072-1092), who was known as Turkan Khatun "The Queen of the Turks" (c. 1055-1094) and enjoyed great influence at court, was a Qarakhanid princess, a daughter of the Tamghach Khan Ibrahim (1038-1068). ${ }^{54}$ His son, Shams al-Mulk Nasr ibn Ibrahim (1068-108o), "Master (Șāhib) of Samarqand, Bukhara, and Mawarannahr," also married Saljuq princesses. ${ }^{55}$

Islamic sources do not contain much information about the Eastern Qarakhanids under the Saljuqs. Ibn al-Athīr recorded that after the conquest of Samarqand in 1089 the Saljuq Sultan Malik Shah I reached Kashghar, and his ruler subjected to the Saljuqs and agreed to mention the name of Malik Shah I in khutba and coinage. ${ }^{56}$ However, Eastern Qarakhanid coins with the names of the Saljuq Sultans have not been found. For this reason, Boris Kochnev assumed that the Saljuqs did not control this territory, or if they did, only for a short period in time..$^{7}$

The Saljuq dominance over the Qarakhanids continued until the battle on the Qatwan steppe in 1141, when the Khitans, who had been defeated by the Jurchens and migrated from China after the collapse of the Liao Empire and established Xi Liao or, as it was known in Islamic sources, the Qara Khitai dynasty (1124-1218), defeated the Sultan of the Saljuq Empire Ahmad Sanjar (1118-1153) and gained supremacy over the region. However, the Qarakhanids did not lose their territories; the Qara Khitai treated them as their subject state and collected annual payments. The interesting thing is that the Saljuqs quickly reestablished their supremacy over the Qarakhanids, at least formally, as the Qarakhanids mentioned the name of Sultan Sanjar in coinage. ${ }^{58}$ It may be understood as a system of "dual vassalage" because the Qarakhanids continued to pay the annual tribute to the Qara Khitai. ${ }^{59}$ However, it seems that the Qarakhanids generally accepted the Saljuq supremacy and did not consider

Al-Kämil fì al-ta'rīkh, ed. Tornberg, vol. 9, 212; Al-Kämil fì al-ta'rïkh, trans. Bulgakov and Kamoliddin, 187.

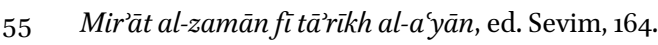

$5^{6}$ Al-Kämil fì al-ta’rīkh, ed. Tornberg vol. 10, 113; Al-Kämil fì al-ta'rīkh, trans. Bulgakov and Kamoliddin, 222-223.

57 Kochnev, Numizmaticheskaia istoriia, 215, 222.

58 Ibid, 225 .

59 For the Qara Khitai political history see Biran, The Empire of the Qara Khitai.
} 
themselves a subject state of the Qara Khitai. The annual payment was understood to be part of a peace treaty and taxes for trade, as it had been practiced before during the Liao Empire.

The Qarakhanid coinage with the name of the Qara Khitai suzerains is considered to be non-existent. Written sources, at least, contain no information on this issue. However, Boris Kochnev identified some Qarakhanid coins with the title of the Qara Khitai rulers but immediately added that they are very rare and the Qara Khitai did not pay much attention to the Islamic traditions of the coinage in the Qarakhanid realm. ${ }^{60}$

\subsection{The Khwarazmshahs}

Khwarazm today is a relatively small region that lies in the lower basin of the Amu Darya and its delta in Central Asia. Khwarazm was incorporated into the Ghaznavid Sultanate at the beginning of the eleventh century and governed by Turkic ghulāms of the Sultan. Along with the title Amir, the Turkic governors also restored the ancient title "Khwarazmshah" meaning "the King of Khwarazm"61 used during the Afrighid dynasty (305-995) in Khwarazm. Later when the Saljuqs conquered Khwarazm in 1040, Turkic ghuläms continued to be used in the governance of this region. For instance, the Saljuq Sultan Malik Shah I appointed Anushtegin Gharchai to this position. During the rule of Malik Shah's son Barkyaruq (1094-1105), the Amir of Khwarazm was Ikkinchi ibn Quchqar. He officially re-established the title "Khwarazmshah." However, the governance later was given to Qutb al-Din Muhammad (1097-1127), the son of Anushtegin Gharchai. ${ }^{62}$ The Anushtegin dynasty (1077-1231), known as the Khwarazmshahs initially were the subjects of the Saljuqs and later also accepted a superiority of the Qara Khitai paying an annual tribute, when Sultan Ahmad Sanjar was defeated by the founder of the Qara Khitai Empire Yelü Dashi (1124-1143) on the Qatwan steppe. For a brief period of time, however, Khwarazm became the center of a major empire that ruled over a large part of Central Asia and Iran.

Moreover, in the late eleventh and twelfth centuries, Khwarazm under the Anushtegins became a hub of the trade routes known as the "Fur Road," connecting the Volga Region with Transoxiana, Khurasan, and China. Khwarazm

\footnotetext{
6o Kochnev, Numizmaticheskaia istoriia, 225-226.

61 Khwarazmshah ("King of Khwarazm") is the ancient title of this region, in use until the nineteenth century.

62 Clifford E. Bosworth, "Khwarazmshahs i. Descendants of the line of Anuštigin," Encyclopcedia Iranica, ed. Ehsan Yarshater (New York: Encyclopædia Iranica Foundation, 2009), online edition, http://www.iranicaonline.org/articles/khwarazmshahs-i.
} 
suffered from the Mongol invasion more than the rest of Central Asia and never regained its previous economic and political splendor.

\section{The Qarakhanids and the East}

The Qarakhanids were surrounded by the steppe empires that rose to power after the collapse of the Tang Empire, the fragmentation of the 'Abbasid Caliphate, and the fall of the Samanid Emirate. The southern and western neighbors of the Qarakhanids were other Turko-Islamic dynasties, while to the east they were bordered by the Xizhou Uyghurs, who were the subjects of the Khitans.

The Khitans were steppe peoples from Manchuria and had once been a part of the Turk Khaganate and the Uyghur Khaganate. They established the Liao Empire in present-day northern China, Mongolia, and part of Siberia and later the Qara Khitai Empire in Central Asia. By the eleventh century, the Liao Empire was very powerful in the region, forcing the Han Chinese Song dynasty to pay an annual tribute.

The Song dynasty succeeded an era of political upheaval known as the period of Wudai shiguo (Five Dynasties and Ten Kingdoms, 907-960), which started with the fall of the Tang Empire in 907. Official missions sent to the Song court by the Qarakhanids mainly fall into the time before the Jurchens had invaded Song China in 1127, which later led to the designations "Northern Song" (96o-1127) and "Southern Song" (1127-126o).

Song China underwent a phase of economic growth unmatched by any earlier period of Chinese history. However, despite its economic strength, the Song dynasty could not dominate its northern neighbors militarily: they were defeated first by the Khitans and later the Jurchens, who succeeded the Khitans to found the Jin Empire, and the Tanguts, who founded the Xi Xia dynasty and controlled the Hexi Corridor, the most important route from Central Asia to China. The rise of the nomadic powers in the north forced the Song dynasty to modify the traditional structure of foreign relations in China.

\subsection{Song China: Fundamental Transformation and Economic Activism}

Historians generally agree that the period from the late Tang to the Song was one of fundamental change and an essential era in shaping early modern China. Chinese culture and society underwent major transformations and developments in philosophy, science, technology, education, arts, economy, and other spheres. Specifically, a number of major economic changes caused rapid development of commerce that had been not previously observed. For 
instance, agricultural productivity increased sharply due to the rise of private property and modifications to the taxation system. Moreover, the previous system of closed and officially controlled city markets was replaced by a network of flexible rural commercial centers that established a national market and linked all areas of commerce to each other. During the transition period from the Tang to the Song, commodities entering the Chinese market expanded from luxury merchandise to daily needs for much of the population. It was a period of the development of transport and communications both overland and sea roads. Moreover, official trade quarters were transformed into autonomous trade associations increasing various kinds of business. ${ }^{63}$ These changes expanded local trade and attracted a wave of foreign merchants to the Chinese market.

The reform movement reached its greatest heights during the reign of Emperor Shenzong under the leadership of Wang Anshi (1021-1086), one of the most renowned statesmen in Chinese history. The first of Wang's "new laws" worked to achieve more flexibility and economy in the transportation of tax grain or tribute to the capital. Generally, this law enabled officials to resell collected commodities and use funds at their disposal to obtain goods required by the state at the most suitable time and place. Later the law was extended to all kinds of basic commodities, a move that greatly reduced the cost of government and served to stabilize prices.

Chinese society became increasingly commercialized in the Song dynasty and the development of neo-Confucianism gradually accepted and supported trade as a legitimate profession. Confucian scholars divided Chinese society into four categories. The highest status was held by shi scholar-officials, following by nong peasants, gong craftsmen, and shang merchants. During the Song period, scholar-officials started to participate in trade, using intermediary agents. ${ }^{64}$ This can be explained by the rise of a new class of scholar-officials who were recruited not only from the aristocracy but also from families of property owners or wealthy merchants and were chosen based on the results of their examinations in the Confucian classics. This means that a new, elite class of civil servants came to power based on merit rather than ancestry.

63 For the great development of commerce during the Song period in China and transformation of Chinese society, see Shiba Yoshinobu, Commerce and Society in Sung China, trans. Mark Elvin (Ann Arbor: The University of Michigan Center for Chinese Studies, 1970). Also see William Guanglin Liu, Chinese Market Economy, 1000-150o (New York: State University of New York Press, 2015).

64 Jacques Gernet, Daily Life in China on the Eve of the Mongol Invasion, 1250-1276 (Stanford: Stanford University Press, 1962), 68-69. 
Therefore, merchants began to gain higher prestige in society and their social status improved significantly.

On the cover of his book on the history of the Song dynasty, Dieter Kuhn pointed out that Song China was "the most advanced civilization on Earth and home to nearly half of humankind." 65 However, the Song, despite its internal development in many areas, was militarily fragile. The new class of scholarofficials did not encourage war, as warfare was discouraged in Confucianism. Therefore, when dealing with foreigners Song emperors sometimes had to act in a way that did not fit with the traditional Chinese world order, where China was considered the center of the world and other polities its tributaries.

The Chinese had had to contend with their northern neighbors, who were mainly pastoral nomads and required Chinese agricultural and manufactured products, well before the Song period. Northerners had raided Chinese territories since ancient times. The Chinese succeeded in conquering and controlling the north during the Han and Tang periods. But when control and defense were not possible, the Chinese had to offer their neighbors something instead of raiding that would bring them mutual benefits. Trade was an option for defense from the northerners for the Chinese and always played a significant role in Sino-nomad relations. Morris Rossabi pointed out that the Chinese originally developed their tributary system of foreign relations as a defense mechanism from peoples in the north. ${ }^{66}$ Scholars generally recognize that Chinese emperors were not greatly enriched by diplomatic gifts from foreign rulers; it was the foreigners who were rewarded with valuable gifts, including access to trade in China. Therefore, the paying of "tribute" was not viewed by "tributaries," especially the representatives of more distant territories, as an act of formal submission but rather as a facilitator for trade - the cost of doing business. ${ }^{67}$

Song shi used the classical Chinese term for gifts from foreign rulers, gong "tribute," which was also applied to Qarakhanid diplomatic gifts. However, taking into account that Chinese rewards for foreign "tributes" were usually equal or sometimes even more valuable, scholars have suggested translating this term as "gifts." 68 The Song emperors had to be flexible and accept their

65 Dieter Kuhn, The Age of Confucian Rule: The Song Transformation of China (Cambridge, Mass.: Belknap Press of Harvard University Press, 2009).

66 Rossabi, China among Equals, 4.

67 Joseph F. Fletcher, "China and Central Asia, 1368-1884," in The Chinese World Order: Traditional China's Foreign Relations, ed. John K. Fairbank (Cambridge: Harvard University Press, 1968), 208.

68 James A. Millward, Eurasian Crossroads: A History of Xinjiang (New York: Columbia University, 2007), 73. Also Hansen, "International Gifting," 276. 
northern neighbors as equals. China's relationship with foreigners was flexible due to its military weakness compared to its powerful nomadic neighbors such as the Khitans and later the Jurchens. For this reason, Song officials adopted a realistic foreign policy. ${ }^{69}$ Song shi used different terms for diplomatic gifts: for distant foreign countries, they applied the term gong, but for the envoys and gifts from the Khitans and the Jurchens the Chinese normally applied the neutral term $h e$, which can be translated as "a congratulatory present." The Khitans also used different terms for the gift exchange with foreigners, mainly gong, he, pin, ${ }^{70}$ and $j i n .{ }^{71}$ For instance, Liao shi applied the term gong for the first envoy from the Qarakhanids and the term jin for the next two envoys, who came to request a marriage alliance.

Studies on Song foreign trade mainly concentrate on the advanced technologies in shipbuilding and the development of maritime roads and networks. During the same period, the Song emperors re-opened and developed overland roads connecting China with Central Asia and India that were used by diplomats, merchants, and monks after the stagnation that followed the fall of the Tang. Tansen Sen clearly stated that the data from the Song period demonstrates the increase of monks traveling from India to China comparing to the previous period..$^{72}$ Merchants also used the overland roads. The Northern Song scholar Li Xin provided an account about preferences of merchants coming along continental and sea roads:

\section{商于海者不宝珠玉则宝犀瑥商于陆者不宝盐铁则宝茶茗 73}

Those who trade by sea, if they do not consider pearl and jade to be precious then they consider rhino horn and tortoiseshells to be precious;

69 Rossabi, China among Equals, 4.

70 Pin is a term used for gift exchanges between "independent countries." For instance, this term applied to the gifts from the Later Liang, the Later Tang, and the Later Zhou dynasties as well as for the Tatars. However, the Tatars were not independent in that period. Karl A. Wittfogel, and Feng Chia-Sheng, History of Chinese Society: Liao, 907-1125 (Philadelphia: American Philosophical Society, 1949), 346. Valerie Hansen suggests that giving this status to the ancestors of the Mongols suited the conditions of the Mongol period, when Liao shi was compiled. Hansen, "International Gifting," $275^{-276}$.

71 Jin is a term used for gift exchanges. It indicated a gift given from a subordinate to a superior and can be translated as "to offer" or "to present."

72 Sen Tansen, Buddhism, Diplomacy, and Trade: The Realignment of Sino-Indian Relations, 6oo-140o (Honolulu: Association for Asian Studies and University of Hawai'i Press, 2003), 13 .

Kuа Aoji, 20: 4b. 
those who trade by land, if they do not consider salt and iron to be precious then they consider tea leaves to be precious.

The Khitans and the Tanguts sought to control the overland trade roads between Central Asia and China. Sources from the Song periods depict foreign caravans coming to China via the Khitan and Tangut territories, clearly showing that this control could be negotiated. When the roads were impassable, merchants could use alternative routes to reach China, as Qarakhanid envoys managed to come to the Song via Tibet.

Shiba Yoshinobu, a prominent scholar of Chinese economic history who was active almost a half-century ago, stated that there is a need for more detailed studies of specific aspects of the Song economy, as for studies on the significance of the great development of commerce at this time and its impact to other social changes. ${ }^{74}$ Many of these aspects have been covered in recent studies on the history of the Song dynasty. ${ }^{75}$ However, research on the impact of the Song commercial transformation on the trade between China and Central Asia and economic changes that occurred in Central Asia remains to be done.

\subsection{Non-Han China: The Liao and the Western Xia}

Song China coexisted with the Khitans and the Tanguts, and later also with the Jurchens, non-Han peoples who controlled major territories that once belonged to the Tang Empire. The Khitans and the Tanguts founded the Liao and the Xi Xia dynasties, which were treated as equals by the Han-Chinese Song dynasty. The Liao is even considered a Chinese dynasty in traditional Chinese historiography and had an official history compiled during the Yuan dynasty (1271-1368). Therefore, even the Qara Khitai dynasty founded by the Khitans in Central Asia was regarded as a Chinese dynasty. But the recognition of the $\mathrm{Xi}$ Xia as a legitimate dynasty of China was brought into question during the Yuan period, and an official dynastic history was never completed. However, the Tanguts are considered "Chinese" in contemporary Chinese historiography, along with the Khitans, the Jurchens, the Mongols, and the Manchus. ${ }^{76}$

\footnotetext{
74 Yoshinobu, Commerce and Society in Sung China, 3.

75 For instance, see Rossabi, China among Equals; Kuhn, The Age of Confucian Rule; Denis C. Twitchett, and Paul Jakov Smith, eds., The Cambridge History of China: The Sung Dynasty and Its Precursors, 907-1279 (Cambridge: Cambridge University Press, 2009), vol. 5 , part 1 .

76 Michal Biran, "The Non-Han Dynasties," in The Blackwell Companion of Chinese History, ed. Michael Szonyi (Oxford: Willey Blackwell, 2017), 130.
} 
By the beginning of the eleventh century the Khitans, former subjects of the Turks, the Uyghurs, and the Tang found themselves in a position of advantage during the disorder in China and on the frontier after the fall of the Uyghur Khaganate in Mongolia and the Tang Empire in China. The Kirghiz from southern Siberia destroyed the Uyghur Khaganate in 840, forcing the Uyghurs to migrate westward, but did not build a new empire, which plunged the steppe into anarchy. For the Kirghiz, a relationship with China and other sedentary civilizations was not a priority. Thomas Barfield specified that it was the main reason for the Kirghiz failure in the region. The Kirghiz looted the Uyghur capital Ordu-Baliq without revitalizing it by restoring connections with China. ${ }^{77}$ This was beneficial for the Khitans who established the Liao Empire in a vast region of Manchuria, northern China, and Mongolia after the fall of the Tang. The Kirghiz and other remaining Turkic elements were driven away from Mongolia and starting from this period, Mongolic peoples dominated in the region. Mongolia became what it is now: Mongolian.

The Khitan expansion of the former Tang territories in the north continued even after the founding of the Song dynasty in 96o. The Song-Khitan confrontation ended with the Chanyuan treaty signed in 1005 and the Song agreed to pay the Liao 200,000 bolts (pi) of silk and 100,000 taels (liang) of silver, officially recorded as a "contribution to military expenses." The Liao and the Song emperors called each other "elder brother" depending on which emperor was born first. Valerie Hansen marked that it was the beginning of a new era in which the Khitans received great wealth and became the leading military power of East Asia. ${ }^{78}$ However, more than half of the annual silver payment was returned to the Song through trade with the Liao. ${ }^{79}$ Therefore, this agreement was beneficial for both sides. Moreover, the Chanyuan treaty clearly defined the frontier and contributed to the long-term stability that enabled commercial relations between the two empires during the eleventh century.

The Liao depended on trade with the Song and managed to build an effective network of overland and sea routes. ${ }^{80}$ The Khitans transported horses,

77 Thomas J. Barfield, The Perilous Frontier: Nomadic Empires and China 221 B.C. to AD 1757 (Cambridge, Mass.: Blackwell Publishers, 1989), 164-165. For the geopolitical change in China and Inner Asia after the collapse of the Uyghur Khaganate in Mongolia, also see Michael R. Drompp, Tang China and the Collapse of the Uighur Empire: A Documentary History (Leiden: Brill, 2005), 197-207.

78 Hansen, "International Gifting," 273.

79 For the details of the Chanyuan treaty, see Herbert Franke, and Denis Crispin Twitchett, eds., The Cambridge History of China: Alien Regimes and Border States, 907-1368 (Cambridge: Cambridge University Press, 1994), vol. 6, 108-110.

Yoshinobu, Commerce and Society in Sung China, 97. 
sheep, fur items, woolen cloth, carpets, brocade, gold and silver objects, iron suits of armor, slaves, and lumber to Song China. The Song trade commodities shipped to the Khitan realm included silk and silk brocade, tea, weapons, marine products, ginger, orange peel, sappanwood, medicines, and gold and silver objects. Exotic goods from Southeast Asia such as incense, spices, tortoiseshell, ivory, pearls, rhino horn, cassia, and probably coral were also shipped via Song China. ${ }^{81}$ The Khitans also exchanged commodities with the Korean kingdom of Koryŏ (918-1392), which sent annual delegations to the Liao court. Additionally, various peoples living in the north of the Liao Empire regularly sent horses, camels, and fur items as tax payments. ${ }^{82}$ The list of these commodities gives us an understanding of trade markets in Liao China and what the Khitans were able to export to their northern and western neighbors.

The Khitans' nearest neighbors in the west were the Tanguts, who originated from the region that includes eastern Tibet, Sichuan, and Gansu, and who founded the Xi Xia Empire after successful campaigns in the Hexi Corridor, the main section of the continental Silk Roads that connected Central Asia with China.

The Tanguts were known in Chinese historical sources as Dangxiang from the seventh century. The name "Tangut" itself first appeared in Orkhon Turkic inscriptions from the eighth century and was also mentioned in Sogdian and Khotanese texts in slightly different forms. ${ }^{83}$ However, it is known that the Tanguts used for self-designation the name "Mi-nyag," and the leading dynasty borrowed the Tang imperial name $\mathrm{Li}^{84}$

The Tangut state was founded in 982 and formally proclaimed as the $\mathrm{Xi}$ Xia dynasty in 1038. The Tangut Empire lasted nearly two hundred years and was destroyed by the Mongols in 1227. At its height, the Tanguts ruled over a multiethnic population in the territory of the Ordos and the Hexi Corridors including Chinese, Tibetans, Uyghurs, and different Qiang and Turkic groups. Therefore, in addition to the Tangut language, Chinese and Tibetan were also officially recognized at the Tangut court. Moreover, the administration followed mainly Chinese models: officials studied Chinese classics both in the original and through Tangut translations in their own writing system. Tibetan

\footnotetext{
81 Ibid, 97; Hansen "International Gifting," 276-28o.

82 Hansen, "International Gifting," 280-283.

83 Evgenii I. Kychanov, Ocherk istorii tangutskogo gosudarstva (Moscow: Nauka, 1968), 21; Ruth W. Dunnell, The Great State of White and High: Buddhism and State Formation in Eleventh-Century Xia (Honolulu: University of Hawai'i Press, 1996), xiii.

84 For more details, see Ruth W. Dunnell, "Who are the Tanguts? Remarks on Tangut Ethnogenesis and the Ethnonym Tangut," Journal of Asian History 18, no. 1 (1984): 78-89.
} 
lamas enjoyed high status at court, as Buddhism was recognized as a state religion and was patronized by the Tangut emperors.

The Tanguts were dependent on the overland trade. Unlike the Khitans, they did not have access to the sea roads and ports connecting them with Song China. The Tanguts had limited resources, so they sought to strengthen their control over trade roads from the west by expanding into the Hexi Corridor. But until the twelfth century, despite their central location, the Tanguts had less trade with the Song than the Khitans or even the Qarakhanids, who had to cross the Hexi Corridor to reach Song China. This is explained by the Tangut's military ambitions, which cause a prolonged war with the Song and sometimes also with the Khitans and the Qarakhanids. The Tangut-Song confrontation finally ended with a treaty in 1044. The Song emperor agreed to send 50,000 taels (liang) of silver, 130,000 bolts ( pi) of silk and 30,000 catties (jin) of tea. However, a sizable portion of that silver flowed back into Song China as a result of trade. ${ }^{85}$ The treaty between the Song and the Xi Xia was also beneficial for Qarakhanid merchants who poured into China after a long interruption due to the military confrontation between the two empires. The Tanguts transported horses, sheep, cattle, camels, and various western goods that they obtained from Qarakhanid merchants to China. The price of a horse during the Song period was equivalent to twenty bolts ( $p i)$ of silk or $50 \mathrm{~kg}$ of tea, ${ }^{86}$ which demonstrates that horses were exchanged mainly for silk and tea at this period.

After the fall of the Liao Empire, the Tanguts established diplomatic relations with the Jurchens and continued trade contacts with its western neighbors throughout the twelfth century, when Central Asia was mostly under the control of the the Qara Khitai. During the Qara Khitai period, Qarakhanid merchants could freely reach at least Turfan, which was also under the Qara Khitai rule as well as have access to the Tangut and Jurchen markets, but nothing is known about Qarakhanid trade in the Southern Song. It seems that from the twelfth century the Tanguts borrowed the role of the Qarakhanids in international trade and acted as middlemen between Central Asia and China.

\subsection{People in the Middle: Uyghurs and Tibetans}

Before coming to Song China, the Qarakhanids passed through the Hexi Corridor, which was under the control of the Ganzhou Uyghurs and later the Tanguts. Additionally, the Qarakhanids bordered with the Xizhou Uyghurs, which had to be crossed to reach the Khitan realm. In theory, Qarakhanid missions could then continue to Song China. They also used the road via the

85 Yoshinobu, Commerce and Society in Sung China, 100-101.

86 Ibid, 101-102. 
Tibetan Tsongkha kingdom. The Ganzhou Uyghurs, the Xizhou Uyghurs, and the Tibetan Tsongkha kingdom appeared in separate sections in Song sources.

After the collapse of the Uyghur Khaganate some Uyghurs migrated to the west fleeing from the Kirghiz attack, and established new polities in Gansu and the Tarim Basin. The first group was known as the Ganzhou Uyghurs and "the other descendants of Xiongnu"87 in Song sources. They succeded in building a new Khaganate and controlling the Hexi Corridor Road in the tenth-eleventh centuries until the Tangut conquest. However, even during the Tangut rule, the Ganzhou Uyghurs continued to be active in commercial affairs and sent trade missions to the Northern Song court. ${ }^{88}$ The Uyghur group that flourished in Turfan was recorded as Xizhou Uyghurs and Gaochang in Song dynasty sources. ${ }^{89}$ Michael Drompp pointed out several factors that allowed the Uyghurs to build their polities in Gansu and the Tarim Basin, such as the fall of the Tibetan Empire (7th-9th centuries), the failure of the Kirghiz to extend their power to the west, and the Chinese lack of interest in controlling affairs in the distant regions, as well as the fact that the Uyghurs were familiar with the Tarim Basin and had had control over the region at various times during the imperial period..$^{90}$ The Hexi Corridor was the main passage for Qarakhanid envoys and caravans at the beginning of the eleventh century. Later they used an alternative road via the Qinghai region in Tibet.

The Qarakhanids sought to establish themselves as middlemen between the Turko-Islamic and the Sino-Tibetan worlds, sending envoys and merchants to polities in Tibet and China along the overland roads. Starting in the second half of the eleventh century their envoys came to Song China via the lands of the Tibetan Tsongkha kingdom. Tsongkha rulers became the main trade partners of the Qarakhanids in Tibet and provided guides and interpreters for Qarakhanid envoys, who accompanied them to China. Chinese historical records are more informative about diplomacy and trade between the Qarakhanids and the

87 Song shi, 490: 14114 .

88 It was only during the Xuanhe era (1119-1125) when the Ganzhou Uyghurs were not allowed to come to the Song court and trade due to the interdict of the Song emperor, Song shi, 490: 14118. For the early history of the Ganzhou Uyghurs, see Elisabeth Pinks, Die Uiguren von Kan-chou in der frühen Sung-Zeit (960-1028) (Wiesbaden: Harrassowitz, 1968).

89 Song shi, 490: 14119. For the history and culture of the Uyghurs in Turfan, see Annemarie von Gabain, Das Leben im uigurischen Königreich von Qočo (850-1250) (Wiesbaden: Harrassowitz, 1973), 2 vols.

Drompp, Tang China and the Collapse of the Uighur Empire, 197-198. 
Tsongkha kingdom. In contrast, Qarakhanid and other Islamic sources provide a very small window on relations with China and Tibet. ${ }^{91}$

Islamic contact with the Tibetans began in the eighth century with military confrontation. It was later intensified by trade, mainly in musk, which was transported from Tibet to the central parts of the Islamic world. ${ }^{92}$ Information about Tibet gathered during this historical phase continued to be used even after the collapse of the Tibetan Empire, despite being out of date. This makes any research on Tibet and its contacts with the Islamic world in the preMongol period more complicated. Therefore, Qarakhanid-Tsongkha relations have not attracted much scholarly attention and there are not many studies on this issue. In this yein, I can only mention Bianca Horlemann's study on the Tibetan Tsongkha kingdom and its relations with neighbor states, wherein the author briefly discussed Tsongkha-Khotan interactions. ${ }^{93} \mathrm{I}$ am not aware of the existence of any records of Qarakhanid-Tsongkha relations in Tibetan sources. Tibetan texts of this period are mainly religious. ${ }^{94}$ Therefore, a depiction of Qarakhanid-Tsongkha relations in Tibet-language sources is unlikely.

With the collapse of the Tibetan Empire in 842, Tibet disintegrated into a number of principalities and until the Mongols, no single polity ruled all of Tibet. This complicates research on international relations between Tibet and its neighbors. ${ }^{95}$ The northeast of Tibetan Amdo, which currently corresponds to the territory divided between Chinese provinces Qinghai, Sichuan, and Gansu, was occupied by the Tsongkha kingdom. ${ }^{96}$ According to the Chinese

91 For Islamic sources on relations between Central Asia and China during the Qarakhanids, see Anya King, "Eastern Islamic Rulers and the Trade with Eastern and Inner Asia in the 1oth-11th Centuries," Bulletin of the Asia Institute, New Series 25 (2011): 175-85.

92 For the Tibetan military assistance to the Turgesh in fighting against the Arabs, see Christopher I. Beckwith, The Tibetan Empire in Central Asia: A History of the Struggle for Great Power among Tibetans, Turks, Arabs, and Chinese during the Early Middle Ages (Princeton: Princeton University Press, 1987), 108-121. For the Tibetan Musk trade, see Anna Akasoy, and Ronit Yoeli-Tlalim, "Along the Musk Routes: Exchanges between Tibet and the Islamic World," Asian Medicine 3 (2007): 217-240; Anna Akasoy. Charles Burnett, and Ronit Yoeli-Tlalim, eds., Islam and Tibet:Interactions along the Musk Routes (Farnham: Ashgate, 2011).

93 Bianca Horlemann, Aufstieg und Niedergang der Tsong-kha-Stammeskonföderation im 11./12. Jahrhundert an der Schnittstelle von Tibet, China und Zentralasien (Frankfurt/Main: Peter Lang, 2004), 100-102.

94 For the discussion of Tibetan texts dealing with this period, see Luciano Petech, "Tibetan Relations with Sung China and with the Mongols," in China among Equals: the Middle Kingdom and its Neighbors, 10th-14th centuries, ed. Morris Rossabi (Berkeley: California University Press, 1983), 174.

95 Ibid, 173.

96 For the political history of the Tsongkha kingdom, see Horlemann, Aufstieg und Niedergang. 
historical records, the founder of the Tsongkha kingdom, Gusiluo (997-1065; reigned 1008-1065), was originally from the royal family of the former Tibetan Empire. ${ }^{97} \mathrm{He}$ was also mentioned as a person from Qocho, a kingdom in Turfan ruled by the Uyghur Idiquts. The Xizhou Uyghurs were a multi-ethnic society with different colonies. Therefore, Gusiluo was not necessarily Uyghur. He could also have been from a Tibetan settlement in Qocho. ${ }^{98}$

Tsongkha was usually referred to generally as Tubo ${ }^{99}$ and more specifically as Qingtang ${ }^{100}$ which was the capital of the kingdom located near the presentday Xining in Qinghai Province. It was a common practice in Chinese traditional historiography to apply designations of central cities to foreign states. In some particular cases, the names of Tsongkha rulers were also used as a designation of the dynasty and the state itself. Qarakhanid and other Islamic sources applied the geographical term Tubbat (Tibet), which was used by Arab-Persian authors starting in the ninth century. ${ }^{101}$ However, the usage of the term is not always clear. Muslim authors did not point to which particular state the term was applied. Moreover, they also frequently used irrelevant information that had been collected during earlier periods. At the same time, some works by Central Asian authors contain descriptions of Tibet, which may refer to Tsongkha. These accounts will be discussed in more detail in Chapter 4 .

The Tsongkha kingdom bordered with the Uyghurs and the Tanguts in the north, Central Tibet in the west, and Northern Song China in the east, and was thus located in the center of the Ancient Tea Horse Road. This trade network originated during the Tang and flourished during the Song period. ${ }^{102}$ Therefore, the Tibetan Tsongkha kingdom occupied a key position in diplomacy and trade with neighboring countries. The ruler of Tsongkha sent an envoy to China for the first time in 1015 and followed a policy of friendship

97 Song shi, 492: 1416o. Also see Petech, “Tibetan Relations," 176.

98 For the origin of Gusiluo, see Bianca Horlemann, "On the Origin of Jiaosiluo, the Founder of the Tsong kha Tribal Confederation in 11th Century Amdo," Zentralasiatische Studien 34 (2005): 127-54.

99 Song shi, 492: 14151-14168.

100 Song shi, 490: 14109, 14124.

101 Hudūd al-'ālam, trans. Minorsky, 92-94; Dīwān lughāt al-Turk, trans. Auezova, 339; Tabāài al-hayawān, ed. and trans. Minorsky, 27-29. Also see Anna Akasoy, "Tibet in Islamic Geography and Cartography: A Survey of Arabic and Persian Sources," in Islam and Tibet: Interactions along the Musk Routes, ed. Anna Akasoy, Charles Burnett, and Ronit Yoeli-Tlalim (Farnham: Ashgate, 2011), 17-41.

102 For the Ancient Tea-Horse Road, see Paul J. Smith, Taxing Heaven's Storehouse: Horses, Bureaucrats, and the Destruction of the Sichuan Tea Industry, 1074-1224 (Cambridge, MA: Council on East Asian Studies, Harvard University Press, 1991); Andrew Forbes, and David Henley, China's Ancient Tea Horse Road (Chiang Mai: Cognoscenti Book, 2011). 
with the Northern Song. ${ }^{103}$ Tsongkha rulers also sought diplomatic contacts with the Liao dynasty and sent seven missions to the Liao court from $105^{1}$ to 1104. ${ }^{104}$ According to Wenchang zalu, they were connected with the Uyghurs, Tanguts, and Qarakhanids. ${ }^{105}$ These connections facilitated the movement of trade commodities to China.

\section{5 Conclusion}

In the tenth century, Turkic peoples started "the first civilizational divide in their history"106 through conversion to Islam. Newcomers in the central Islamic lands via conversion quickly took leadership positions in military and administrative institutions. The mass Islamization process among the Turkic peoples in the Eurasian steppes brought about the creation of the first Turko-Islamic culture and the new image of the Turks spread through the Islamic world and China.

After the rise of the first Turko-Islamic empires, the Turks, who were represented as enemies of Islam in the early 'Abbasid period, began to be characterized by Arab and Persian writers as "pure Muslims" originating from the Iranian world. Muslim historians who served Turkic rulers argued that the Turks were the descendants of Afrasiyab, a legendary king of Turan in ancient Iranian mythology ${ }^{107}$ This contributed to the new positive image of the Turks in the Islamic world and reflected on their representation in China. The Turks rapidly began to be closely associated with Islamic culture in Chinese historiography.

By the eleventh century, the Qarakhanids incorporated the kingdoms of Khotan and Kucha into the Khaganate and obtained direct access to the main trade routes of the northern and southern Silk Roads. Their Islamic culture served as a tool to enter and become a part of the Muslim world. At the same time, the Qarakhanids preserved their Turko-nomadic traditions and heritage, which facilitated their commercial presence in the East.

\footnotetext{
103 Song shi, 8: 158; 492: 14161.

104 Liao shi, 20: 243, 246; 22: 268, 270; 23: 277, 320, 321.

105 Wenchang zalu, 1: 2. For relations between Tsongkha and Uyghur principalities in Gansu, Kucha and Turfan, see Bianca Horlemann, "The Relations of the Eleventh-Century Tsong Kha Tribal Confederation to Its Neighbour States on the Silk Road," in Contributions to the Cultural History of Early Tibet, ed. Matthew Kapstein, and Brandon Dotson (Leiden: Brill, 2007), 88-100.

106 Carter V. Findley, The Turks in World History (Oxford: Oxford University Press, 2005), 56.

107 For the new perspective on the Turks in the late Arabic historiography, also see Frenkel, The Turkic Peoples, 21-24.
} 